\title{
Partner Facilities Working Group (PFWG) Meeting
}

May 24-25, 2017

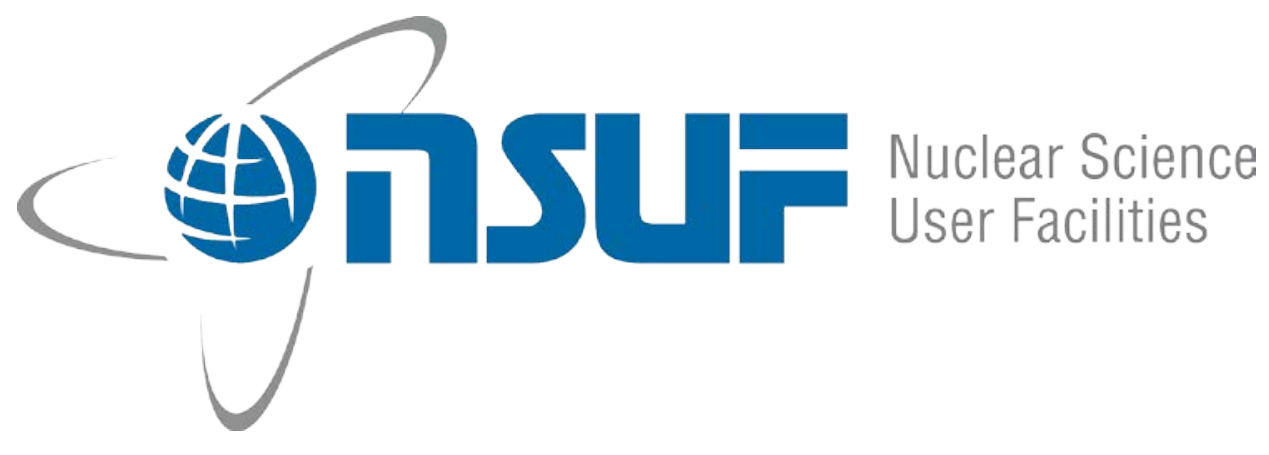




\section{CONTENTS}

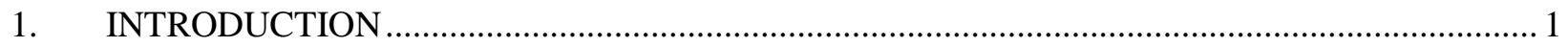

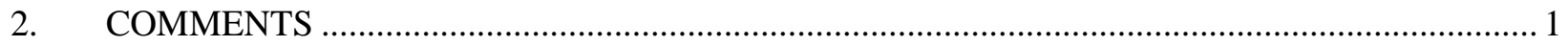

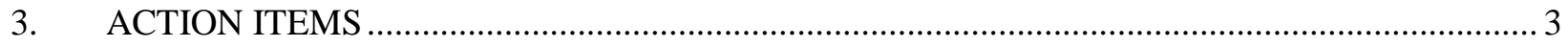

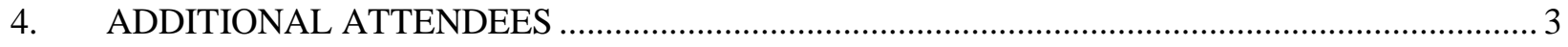

ATTACHMENT A, ATTENDEES AND AGENDA...................................................................... 4 


\section{Partner Facilities Working Group (PFWG) Meeting}

\section{INTRODUCTION}

The Nuclear Science User Facilities (NSUF) program convened the PFWG meeting to provide a formal venue to capture valued input from the NSUF partner facilities. The general topics of discussion included:

- $\quad$ Memorandums of understanding (MOU)

- User agreements

- $\quad$ Proposal rules and guidelines

- Facility reviews

- $\quad$ Establishment of standing working committees for the PFWG.

In addition, each partner facility provided a short presentation on its capabilities and contributions to the NSUF.

\section{COMMENTS}

NSUF petitioned support from the PFWG in the following areas:

- $\quad$ Completing an MOU for each partner facility

- Planning PFWG involvement in and support of proposal feasibility reviews, proposal relevancy reviews, proposal technical reviews, and establishment of application guidelines for rapid turnaround experiments (RTEs)

- Refining descriptions of each facility and capability for the NSUF website

- Establishing ideas and a process for partner facility reviews and outcome actions.

Throughout the meeting, the following questions were raised:

- Who is responsible for NSUF forward thinking? Should the PFWG be involved?

- Can NSUF help programs maintain committed facilities? Is this part of the MOU commitment?

- Should user agreements include criteria for unused samples? 
- Should partners have their own user agreements (for RTEs)?

- Should milestones be added to user agreements? Should the milestones coincide with sample availability?

- What are the sample transport rules of engagement (allocation, timing)?

- Can the PFWG expand the timeline of RTE experiments? Can the timing be split? How can the compressed times for feasibility reviews be remedied?

- What happens if something breaks? Can NSUF establish a contingency fund?

- Should NSUF require business plans for the infrastructure calls to outline how they will maintain the new facility or equipment?

- Can funding be provided for non-DOE-NE relevant projects?

- Can funding or additional support staff be provided to partner facilities to support proposals?

- $\quad$ Can NEUP funding be coupled with NSUF access (integrating funding and schedule)?

- Can NSUF accept funds from other offices (e.g., DOE Office of Science)?

- Can NSUF develop mechanisms for universities to apply and receive samples from the Nuclear Fuels and Materials Library at no cost (may require liability review for sending to non-NSUF facilities)?

- Can NSUF develop and coordinate “user weeks”?

Areas identified for improvement included:

- $\quad$ Expanding inadequate RTE scopes

- $\quad$ Training for principal investigators

- Ensuring samples are available to meet specified schedules (enforce availability prior to proposal submittal)

- Establishing guidance for standard items and services (identify triggers that raise costs)

- Developing checklists to assist principal investigators

- Assigning technical leads at the project site (defining information for what kind of sample is needed for a facility or technique 
- Requiring a project execution plan.

It is anticipated that the questions and areas identified for improvement will be assigned to newlydeployed PFWG committees for investigation and proposed remedies to NSUF program management. In addition, the PFWG finds value in convening at least annually to share lessons learned and improve processes and working relationships among the NSUF PFWGs.

\section{ACTION ITEMS}

NSUF program management will:

- Distribute an NSUF organization chart with names

- Identify potential committees and develop subsequent charters

- Add sample ownership to Nuclear Fuels and Materials Library and MOUs.

\section{ADDITIONAL ATTENDEES}

In addition to the individuals listed in the as-executed agenda (see Attachment $\mathrm{A}$ ), the following individuals attended the meeting, either in whole or in part:

Assel Aitkaliyeva, University of Florida

Lisa Aldrich, Idaho National Laboratory

Keith Lockie, DOE Idaho Operations Office

Linda McCoy, DOE Idaho Operations Office

Erin Searcy, Idaho National Laboratory 


\section{Attachment A \\ Attendees and Agenda}

ตnisure

\section{NSUF Partner Facilities Working Group \\ (PFWG) Meeting \\ Wednesday \& Thursday, May 24 \& 25}

Objective: Provide a formal venue to capture valued input from NSUF Partner Facilities

Attire: Business Casual

Todd Allen

University of Wisconsin-Madison

Raymond Cao

The Ohio State University

Lynne Ecker

Brookhaven National Laboratory

Frank Gift

Westinghouse

Alan Gunn

Department of Energy-Idaho Operations Office

Don Hansen

Sandia National Laboratories

Thomas Hartmann

University of Nevada-Los Vegas

Khalid Hattar

Sandia National Laboratories

Ayman Hawari

North Carolina State University

Li He

University of Wisconsin-Madison

Peter Hosemann

University of California-Berkeley

Gordon Kohse

Massachusetts Institute of Technology

Meimei Li

Argonne National Laboratory

\author{
Kory Linton \\ Oak Ridge National Laboratory \\ Mitchell Meyer \\ Idaho National Laboratory \\ Tom Miller \\ Department of Energy-Nuclear Energy \\ Christian Petrie \\ Oak Ridge National Laboratory \\ Tarik Saleh \\ Los Alamos National Laboratory \\ David Schoonen \\ Idaho National Laboratory \\ David Senor \\ Pacific Northwest National Laboratory \\ Joanna Taylor \\ Center for Advanced Energy Studies \\ Jeff Terry \\ Illinois Institute of Technology \\ Juersen Thieme \\ Brookhaven National Laboratory \\ Jitendra Tripathi \\ Purdue University \\ Ovidiu Toader \\ University of Michigan \\ Sven Van den Berghe \\ SCK-CEN
}

NSUF Partner Facilities Working Group Meeting 


\section{(4) \\ Wednesday, May 24}

Center for Advanced Energy Studies (CAES) Auditorium (2 ${ }^{\text {nd }}$ Floor)

8:00 Computer Network Setup.

CAES IT Staff

8:30 Welcome and Introductions

Rory Kennedy

Director, NSUF

8:50 Welcome from DOE-ID

TBD

Principal Deputy Manager, Nuclear Energy, DOE-ID

9:05 Welcome from DOE-NE

Tom Miller

Director of Accelerated Innovation in Nuclear, DOE-NE

9:20 Overview of Agenda Rory Kennedy

9:30 NSUF Overview/Status.

Rory Kennedy

10:15 Break

10:45 NSUF Partner Facilities Topics of Discussion

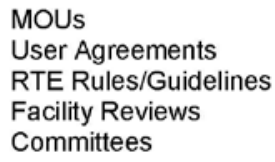

12:15 Working lunch - NSUF PFWG Committee Assignments Discussion.

Lunch invitees:

Todd Allen, $\mathrm{U}$ of W-Madison

Christian Petrie, ORNL

Raymond Cao, OSU

Tarik Saleh, LANL

Lynne Ecker, BNL

Dave Schoonen, INL

Frank Gift, Westinghouse

Dave Senor, PNNL

Don Hansen, Sandia

Joanna Taylor, CAES

Thomas Hartmann, $\mathrm{U}$ of $\mathrm{N}$-Las Vegas

Juersen Thieme, BNL

Khalid Hattar, SNL

Jitendra Tripathi, Purdue

Ayman Hawari, NCSU

Ovidiu Toader, $\mathrm{U}$ of $\mathrm{M}$

$\mathrm{Li} \mathrm{He}, \mathrm{U}$ of W-Madison

Sven Van den Berghe, SCK-CEN

Peter Hosemann, $\mathrm{U}$ of C-Berkeley

Jeff Benson, INL

Gordon Kohse, MIT

Brenden Heidrich, INL

Meimei Li, ANL

Rory Kennedy, INL

Kory Linton, ORNL

Dan Ogden, INL

Mitch Meyer, INL

Renae Soelberg, INL

Tom Miller, DOE-NE

NSUF Partner Facilities Working Group Meeting 


\section{(4) 2 Nuclear Science

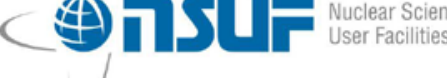

Wednesday, May 24

Center for Advanced Energy Studies (CAES) Auditorium (2 ${ }^{\text {nd }}$ Floor)

Short Partner Facility Presentations

1:15 Idaho National Laboratory

Mitch Meyer \& Dave Schoonen

1:45 Massachusetts Institute of Technology Gordon Kohse

2:15 Center for Advanced Energy Studies Joanna Taylor

2:45 North Carolina State University Ayman Hawari

3:15 Break

3:45 University of Nevada-Las Vegas Thomas Hartmann

4:15 University of Michigan Gary Was

4:45 Illinois Institute of Technology Jeff Terry

5:15 Oak Ridge National Laboratory Kory Linton

5:45 Adjourn

6:30 Working dinner at Stockman's to discuss NSUF PFWG Committee Charters Dinner invitees:

Todd Allen, $\mathrm{U}$ of W-Madison

Raymond Cao, OSU

Lynne Ecker, BNL

Frank Gift, Westinghouse

Don Hansen, Sandia

Thomas Hartmann, $\mathrm{U}$ of $\mathrm{N}$-Las Vegas

Khalid Hattar, SNL

Ayman Hawari, NCSU

$\mathrm{Li} \mathrm{He}, \mathrm{U}$ of W-Madison

Peter Hosemann, $\mathrm{U}$ of C-Berkeley

Gordon Kohse, MIT

Meimei Li, ANL

Kory Linton, ORNL

Mitch Meyer, INL

Tom Miller, DOE-NE
Christian Petrie, ORNL

Tarik Saleh, LANL

Dave Schoonen, INL

Dave Senor, PNNL

Joanna Taylor, CAES

Juersen Thieme, BNL

Jitendra Tripathi, Purdue

Ovidiu Toader, $\mathrm{U}$ of $\mathrm{M}$

Sven Van den Berghe, SCK-CEN

Jeff Benson, INL

Brenden Heidrich, INL

Rory Kennedy, INL

Dan Ogden, INL 


\section{(4) Nuclear Science \\ (4) D U User Facilities}

Thursday, May 25

Center for Advanced Energy Studies (CAES) Auditorium (2 ${ }^{\text {nd }}$ Floor)

Short Partner Facility Presentations

8:30 Purdue University

Jitendra Tripath

9:00 University of California-Berkeley

Peter Hosemann

9:30 University of Wisconsin-Madison.

Todd Allen

10:00 Pacific Northwest National Laboratory.

David Senor

10:30 Break

11:00 Westinghouse

Frank Gift

11:30 Argonne National Laboratory.

Meimei Li

12:00 Working lunch to review Nuclear Energy Infrastructure Database (NEID) and Nuclear Fuels \& Materials Library (NFML).

Brenden Heidrich

Lunch invitees:

Todd Allen, $\mathrm{U}$ of W-Madison

Christian Petrie, ORNL

Raymond Cao, OSU

Tarik Saleh, LANL

Lynne Ecker, BNL

Dave Schoonen, INL

Frank Gift, Westinghouse

Dave Senor, PNNL

Don Hansen, Sandia

Joanna Taylor, CAES

Thomas Hartmann, $\mathrm{U}$ of $\mathrm{N}$-Las Vegas

Juersen Thieme, BNL

Khalid Hattar, SNL

Jitendra Tripathi, Purdue

Ayman Hawari, NCSU

Ovidiu Toader, $\mathrm{U}$ of $\mathrm{M}$

$\mathrm{Li} \mathrm{He}, \mathrm{U}$ of W-Madison

Sven Van den Berghe, SKC-CEN

Peter Hosemann, $U$ of C-Berkeley

Jeff Benson, INL

Gordon Kohse, MIT

Kelly Cunningham, INL

Meimei Li, ANL

Brenden Heidrich, INL

Kory Linton, ORNL

Rory Kennedy, INL

Mitch Meyer, INL

Jon Kirkham, INL

Tom Miller, DOE-NE

Dan Ogden, INL

Renae Soelberg, INL

1:00 Sandia National Laboratories

Khalid Hattar

1:30 Brookhaven National Laboratory Lynne Ecker

2:00 Los Alamos National Laboratory. . Tarik Saleh

NSUF Partner Facilities Working Group Meeting 


\section{(4)}

Thursday, May 25

Center for Advanced Energy Studies (CAES) Auditorium (2 ${ }^{\text {nd }}$ Floor)

$2: 30 \quad$ The Ohio State University .......................................................... Raymond Cao

3:00 Belgium Nuclear Research Centre ............................................ Sven Van den Berghe

3:30 Summary and Wrap-Up

NSUF Partner Facilities Working Group Meeting 